九州大学学術情報リポジトリ

Kyushu University Institutional Repository

\title{
Two Isolates of Cucumber Mosaic Cucumovirus Expressing Mild Mosaic Symptoms on Tobacco Plants
}

Takanami, Yoichi

Laboratory of Plant Pathology, Graduate School of Bioresource and Bioenvironmental Sciences, Kyushu University

Kikuhara, Kenji

Laboratory of Plant Pathology, Graduate School of Bioresource and Bioenvironmental Sciences, Kyushu University

Takeshita, Minoru

Laboratory of Plant Pathology, Graduate School of Bioresource and Bioenvironmental Sciences, Kyushu University

https://doi.org/10.5109/24249

出版情報: 九州大学大学院農学研究院紀要. 43 (1/2)，pp.53-58，1998-11. Kyushu University バージョン：

権利関係 : 
J. Fac. Agr., Kyushu Univ., 43 (1·2), 53-58 (1998)

\title{
Two Isolates of Cucumber Mosaic Cucumovirus Expressing Mild Mosaic Symptoms on Tobacco Plants
}

\author{
Yoichi Takanami, Kenji Kikuhara* and Minoru Takeshita \\ Laboratory of Plant Pathology, Graduate School of Bioresource and Bioenvirommental Sciences, \\ Kyushu University, Fukıoka 812-8581, Japan \\ (Received June 30, 1998 and accepted August 7, 1998)
}

\begin{abstract}
Two cucumber mosaic virus (CMV) isolates that induce mild mosaic symptoms in tobácco (Nicotiana tabacum L.) were characterized by symptom observation, serological tests and the nucleotide sequences of viral RNA. CMV-m2 but not CMV-m1 elicited necrotic etching symptom in the inoculated leaves of tobacco. CMV-m1 and CMV-m2 exhibited different. scrological properties. Comparison of the nucleotide sequences of RNA3s showed that CMV-m2 belongs to subgroup II of CMV. CMV--ml was suggested to belong to subgroup I with serological test and symptomatology. The two isolates that induce very mild mosaic symptoms in tobacco but. belong to different subgroups of CMV would greatly facilitate the study on the molecular basis of cross-protection of plant viruses.
\end{abstract}

\section{INTRODLCTION}

Cucumber mosaic virus (CMV) is the type member of Cucumovirus in the family of Bromoviridae which has commonly a functionally divided genome of single-stranded, plus sense RNA molecules, namely RNA1, RNA2 and RNA3, in decreasing order of molecular weight. CMV RNAs 1 and 2 were experimentally demonstrated to be involved in viral RNA replication (Nitta $e t a l ., 1988$ ) and expression of both the 3a protein (MP) and the coat protein (CP) encoded by RNA3 was shown to be indispensable for virus transport (Suzuki et al., 1991). CMV is distributed worldwide and exists as a variety of strains or isolates that differ in host range and pathogenicity (reviewed in Palukaitis et al., 1992). CMV is divided into subgroups I and II based on the serological properties and differences in nucleotide sequence.

Many efforts have been made to prevent the enormous damages on agricultural crop production caused by CMV. There are a number of studies that describe the establishment of CMV resistance in transgenic plants which express the gene of CMV coat protein, non-structural protein or satellite RNA (Fitchen and Beachy, 1993). The principle of these strategies is based on "cross-protection" of plant viruses. We are now investigating the molecular basis of the phenomenon using various CMV isolates. In the course of our study, it became necessary to characterize CMV isolates that express attenuated symptoms on tobacco plants.

Several strains (isolates) of CMV have been isolated from tobacco plants (Nicotiana tabacum L.) in Japan (Hidaka and Tomaru, 1960; Tomaru and Hidaka, 1960a, b; Tomaru and Udagawa, 1967; 1970). Among the isolates, a mild strain (CMV-C) (Tomaru and Hidaka, 1960a) and a yellow mild mottle strain (CMV-YM) (Tomaru and Udagawa, 1970)

*Present address: Fukıoka Prefectural Government Office, 812-8577, Japan 
were reported to induce mild mosaic symptoms in tobacco. Since an isolate of CMV in a sample batch which had originally been isolated and stored as CMV-C by Tomaru and Hidaka (1960a) was revealed to belong to subgroup II in this study, we designated the isolate as CMV-m2. CMV-YM has already been repoted to contain a satellite RNA that was named Y-satRNA and was capable of inducing brilliant yellow mosaic on tobacco (Takanami, 1981). A satellite-free isolate of CMV-YM that had been prepared as described previously (Takanami, 1981) has been shown to induce very mild green mosaic on tobacco (unpublished). Present study also revealed that the satellite-free isolate derived from CMV-YM belongs to subgroup I, and was named CMV-m1. This paper describes the characteristics of the both CMV isolates expressing the attenuated symptorns in tobacco.

\section{MATERIALS AND METHODS}

\section{CMV isolates}

CMV $-\mathrm{m} 1$ and $\mathrm{CMV}-\mathrm{m} 2$ were as described above. CMV-Y (Tomaru and Hidaka, 1960) and CMV-O (Hidaka and Tomaru, 1960) were used for comparison. Both of the isolates were shown to belong to subgroup I based on the sequencing results (Nitta et al., 1988; Hayakawa et al., 1989). CMV-GT isolated from a tomato plant in Gunma Prefecture belongs to subgroup II (Dr. Hanada, personal communication).

\section{Virus propagation and purification}

CMV isolates were propagated in tobacco (N. tabacum cv. Xanthi-nc) and purified as described previously (Takanami, 1981).

\section{Serological test}

Immunodiffusion tests of CMV were carried out essentially according to Ohki and Inouye (1987) using purified virions of the CMV isolates and antisera against CMV-Y and CMV-P (subgroup II) raised in rabbits. The antisera of CMV-P was provided by Dr. Hanada.

\section{cDNA cloning and sequencing of the cDNA}

CDNA cloning and sequencing of CMV-m2 RNA3 was performed according to the methods adopted for RNA3s of CMV-KM and CMV-D8 (Takeshita and Takanami, 1997).

\section{RESULTS}

\section{Symptoms of tobacco plants inoculated with CMV-m1 and CMV-m2}

Young tobacco plants (cv. Xanthi-nc) were mechanically inoculated with crude saps of tobacco plants that had been infected with CMV-m1 or CMV-m2, and the symptoms appeared on the plants were observed. CMV-m2 induced necrotic etching symptom but $\mathrm{CMV}-\mathrm{ml}$ produced no apparent symptoms on the inoculated leaves of tobacco (Fig. 1). It is well known that the necrotic etching symptom in the inoculated leaves of tobacco is characteristic for subgroup II CMV (Zhang et al., 1994). Both isolates induced very mild green mosaic symptoms which were apparently indistinguishable from those in healthy 
control tobacco especially in the latter stages of infection (Fig. 1).
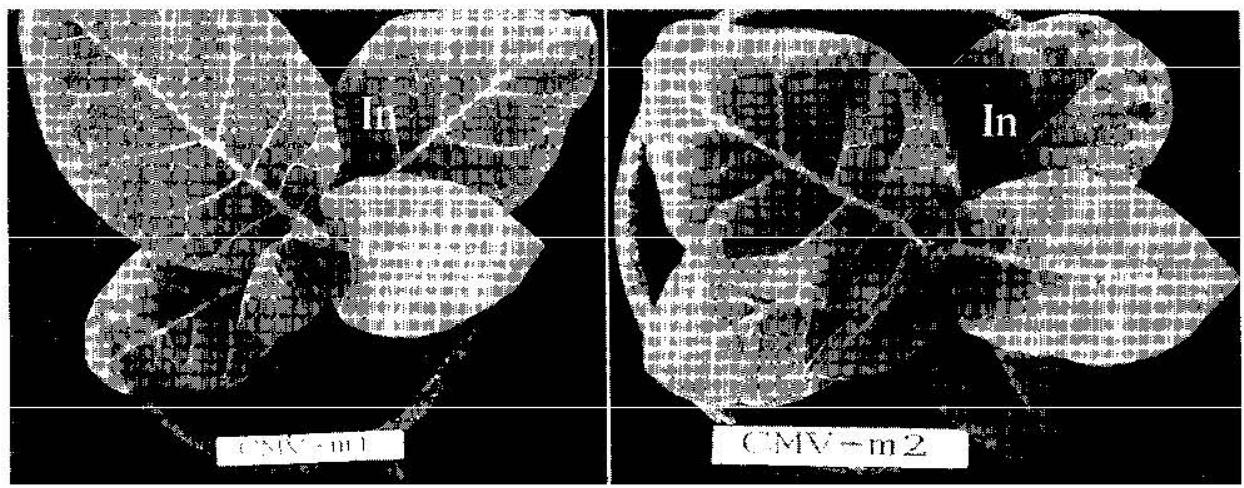

Fig. 1. Symploms of tobacco (N. tabacum ev. Xanthi-ne) inoculated with CMV m1 (left) and CMV-m2 (right) I4 days after inoculation. (In) indicates the inoculated leaves.

\section{Double-immunodiffusion tests}

As shown in Fig. 2A, when the central well was filled with the antiserurn against CMV-Y and the outer wolls were with the purified CMV virions as antigens, the precipitation lines of $\mathrm{CMV}-\mathrm{m} 1$ and $\mathrm{CMV}-\mathrm{Y}$ completely fused each other and those of CMV-m2 and CMV-GT also fused, although spur-precipitin lines were formed between CMV-Y and CMV-m2, CMV-ml and CMV-m2, and CMV-m1 and CMV-GT. The completely fused precipitation lines were formed between CMV-m2 and CMV-GT and the spur-precipitation lines were between CMV-O and CMV-GT, CMV-O) and CMV-m2, $\mathrm{CMV}-\mathrm{Y}$ and $\mathrm{CMV}-\mathrm{m} 2$, and $\mathrm{CMV}-\mathrm{Y}$ and $\mathrm{CMV}-\mathrm{GT}$, irrespective as to whether the antiserum
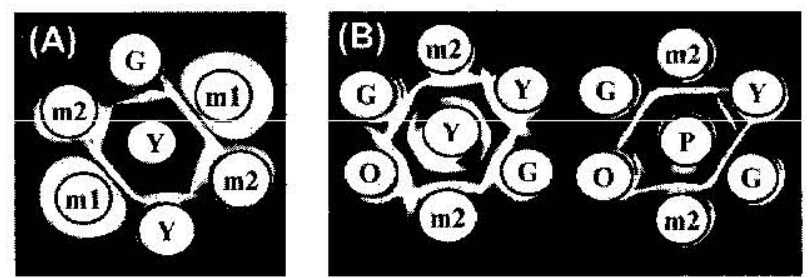

Fig. 2. Double immunodiffusion tests of CMV isolates. (A); the central well was filled with CMV-Y antiscrum diluted 6 times with $0.1 \mathrm{M}$ sodium phosphlate buffer, $\mathrm{pH} 7.0$, containing $0.15 \mathrm{M} \mathrm{NaCl}$ (PBS). The peripheral wells contained 1 mig/nil of purified CMV - mil (mi), - m2 $(\mathrm{m} 2),-\mathrm{Y}(\mathrm{Y})$ and $-\mathrm{G}^{\prime} \mathrm{J}(\mathrm{G})$. (B); the central wells in the left and right plates were filled with $\mathrm{CMV}-\mathrm{Y}$ and $\mathrm{CMV}-\mathrm{P}$ antisera, respectively, which were diluted 6 times with PBS. The peripheral wells contained $1 \mathrm{mg} / \mathrm{ml}$ of purified CMV $-\mathrm{m} 2(\mathrm{~m} 2),-\mathrm{Y}(\mathrm{Y}),-\mathrm{GT}(\mathrm{G})$ and $-\mathrm{O}(\mathrm{O})$ ). Photographs were laken $24 \mathrm{~h}$ after incubation at $28^{\circ} \mathrm{C}$. 
against CMV-Y or CMV-P was placed in the central well (Fig. 2A). These results clearly demonstrated that CMV-m1 and CMV-m2 belong to subgroup I and subgroup II, respectively, on the basis of serological property.

\section{Nucleotide sequence of CMV-m2 RNA3}

The complete nucleotide sequence of CMV-m2 RNA3 was submitted to the DDBJ/GenBank/EMBL DNA data base as the accession number of AB006813. The sequences of the 5' noncoding regions in RNA3s of CMV-m2, CMV-Y (Nitta et al., 1988) and CMV-Q (Davis and Symons, 1988) were aligned in Fig. 3. There found long inscrtions and deletions in the 5 ' regions among the isolates and the structural feature of

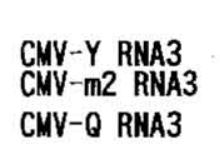

CMV-Y RNA3

CNV-m2 RNA3 CNV-Q RNA3

CMV-Y RNA3

CMV-m2 RNA3 CMV $-Q$ RNA3

CMV-Y RNA3

CMV-T2 RNA3 CNV-Q RNA3

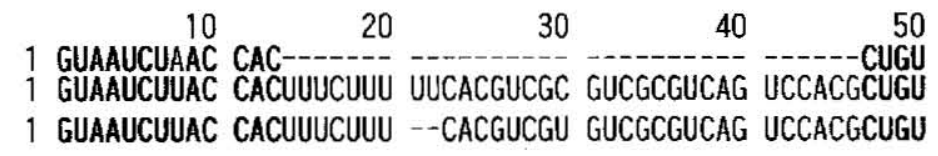

60

$70 \quad 80 \quad 90$

51 GUGUGUGUGU GUGUGUAUCG AGUCGUGUUG UCCGCACAUU -------UGA

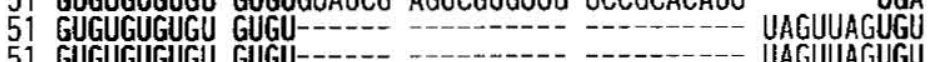

51 GUGUGUGUGU GUGU- UAGUUAGUGU

110

120

130

140

150

101 GUCGUGUUGU CCGCACAUAU AUAUUUAUUU CGUUGUACAG UGUGUUAGAU

101 GUCGUGUU-- -

101 GUCGUGUU--

160

151 UUCCCGAGGC - AUG

151 UACG-GAGGU UAUG

151 UACG-AAGGU UAUG

Fig. 3. Alignment of the 5 ' noncoding regions in RNA3s of CMV -Y, CMV-m2 and CMV-Q. The sequence data of CMV-Y and CMV-Q were refereed to Nitta et al. (1988) and Davis and Symons (1988), respectively. Dots (-) represent deletions and mucleotides common to the three isolates are shown in bold letters. Underlines show the start codons of the open reading frame for $3 a$ protein.

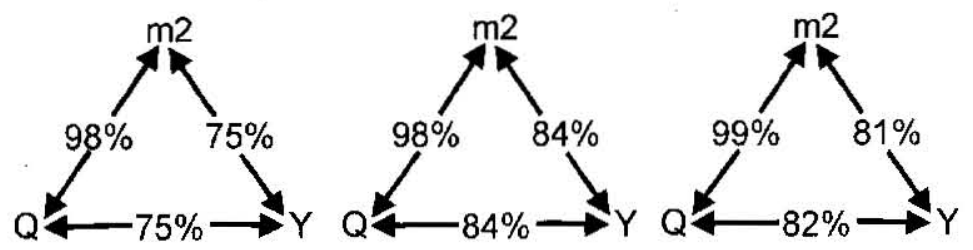

Fig. 4. Similarity in entire nucleotide sequences of RNA3s and amino acid sequences of the $3 \mathrm{a}$ and coat protcins of three $\mathrm{CMV}$ isolates. The sequence data of $\mathrm{CMV}-\mathrm{Y}$ and $\mathrm{CMV}-\mathrm{Q}$ were refereed to Nitta et al. (1988) and Davis and Symons (1988), respectively. m2: CMV-rm2, Y : CMV-Y: Q : CMV-Q. 
the region of $\mathrm{CMV}-\mathrm{m} 2$ was almost the same as that of $\mathrm{CMV}-\mathrm{Q}$ belonging to subgroup II. In addition to the serological property of the isolate, the alignment suggested that CMV-m2 is a member of subgroup II of CMV. Comparison of the entire nucleotide sequences of RNA3s and amino acid sequences of the $3 \mathrm{a}$ and coat proteins of the isolates further confirmed the result (Fig. 4).

\section{DISCUSSION}

CMV-m2 was found in the samples that had been long time stored as a mild strain, CMV-C, under lyophilized conditions (Tomaru and Hidaka, 1960). Our present study clearly demonstrated that CMV-m2 belongs to subgroup II of CMV. A serological study on the CMV isolates (Kiriyama, 1972), however, showed that CMV-C used in his study formed precipitation lines completely fused with those of CMV-Y and CMV-O, suggesting that the virus would be of subgroup 1. On the other hand, a study on interference among CMV strains (Tomaru et al., 1967) reported that only CMV-C showed incomplete cross-protection against other CMV strains, suggesting that CMV-C used in this study would have properties somewhat different from those of the other isolates. Furthermore, the original report concerning $\mathrm{CMV}-\mathrm{C}$ (Tomaru and Hidaka, 1960) recorded the induction of the necrotic etching symptoms (originally described as necrotic lesions with irregular shape) in the inoculated leaves of several tobacco varieties by CMV-C. The samples stored as CMV-C might contain CMV belonging to both subgroup I and II, which commonly induced mild mosaic symptoms in tobacco.

CMV-m1 produced very mild systemic symptoms in tobacco indistinguishable from thase of $\mathrm{CMV}-\mathrm{m} 2$ although the present study suggested that it belongs to subgroup I from the serological test and symptoms in the inoculated leaves of tobacco. Nucleotide sequencing of genome RNAs of CMV-m1 has not yet finished but CMV-m1 RNAs was probed to hybridize specifically with synthetic DNA probe designed for detection of subgroup I CMV RNAs (will be described elsewhere).

The two CMV isolates that induce very mild mosaic symptoms in tobacco but belong to different subgroups would greatly facilitate the study on the molecular basis of cross-protection of plant viruses.

\section{ACKNOWLEDGEMEN'T}

The authors gratefully acknowledge Dr. Hanada, Kyushu National Agricultura! Experiment Station, Kumamoto, Japan for his kind gift of CMV-GT and antiserum against CMV-P. This work was partly supported by Grants-in-Aid for Scientific Research (A) 08406004 from The Ministry of Education, Science, Sports and Culture, Japan.

\section{REFERENCES}

Davis, C. and R. H. Symons 1988 Further implications for the evolutionary relationships between tripartite plant viruses based on cueumber mosaic virus RNA3. Virology, 165: 216-224

Fitchen, J. H. and R. N. Bcachy 1993 Genctically engineered protection against viruses in transgenic plants. Annu. Rev. Microbiol., 47: 739-763

Ilayakawa, '1., M. Mizukami, M. Nakajina and M. Suzuki 1989 Complete nucleotide sequence of RNA3 from cucumber mosaic virus (CMV) strain (): Comparative study of nucleotide sequences and amino 
acid sequences among CMV strains $O, Q, \mathrm{D}$ and $\mathrm{Y} . J$. Grz. Virol, 70:499-504

Hidaka, \% and K. Tomaru 1960 Strains of cucumber mosaic virus isolated from tobacco plants. 1. Ordinary strain. Bull. Hatarw Tob. Exp. Sta, 46: 125-134

Kiriyama, K. 1972 Purification and serological studies on cucumber mosaic virus. Bull. Morioka Tob. Exp. Sta., 8: $39-98$

Nitta, N., C. Masuta, S. Kuwata and Y. Takanami 1988 Comparative studies or the nucleotide sequence of cucumber mosaic virus RNA3 hetween Y strain and Q strain. Ann. Phytopath. Soc. Jpn., 54: $516-522$

Ohki, S. T. and T. Inouye 1987 Use of gelrite as a gelling agent in immunodiffusion tests for identification of plant virus antigens. Ann. Phytopath. Soc. Jpn, 53:557-561

Palukaitis, P., M. J. Roossinck, R. G. Dietzgen, and R. I. 13. Fratlcki 1992 Cucumber mosaic virus. Adt: Vimis Res., 41: $281-348$

Takanami, Y. 1981 A striking ehange in symptoms on curcumber mosaic virus-infected tobaceo plants induced by a satellite RNA. Virology, 109: 120-126

Takeshita, M and Y. Takanami 1997 Complete mucleotide sequences of RNA.3s of cucumber mosaic virus KM and D8 strains. J. Fac: Agric. Kyushu Linia., 42: 27-32

Tomaru, K. and Z. Hidaka 1960)a Strains of cucumber mosaic virus isolated from tobacco plants. II. A mild strain. Bull Hatano Tob. Exp. Sta, 46: 135-142

Tomaru, K. and Z. Hidaka 1960b Strains of cucumber mosaic virus isolated from tobacco plants. 11. A ycllow strain. Bull. Hataro Tob. Exp. Sta., 46: 143-149

Tomarı, K., 7. Hidaka and A. Udagawa 1967 Strains of cucumber mosaic virus isolated from tobacco plants. V. Stucties on interference amomg cueumber mosaic virus strains. Bull. Hatano Tob. Exp. Sta., 58: 79-88

Tomaru, K. and A. Udagawa 1970 Strains of cucumber mosaic virus isolated from tobacco plants V1. A ycllow mild mottle strain Ann. Phytopath. Soc. Jph, 36: 87-93

Zhang, L., K. Hanada and P. Palukaitis 1994 Mapping local and systemic symptom determinanis of cucunber mosaic cuemovirus in tobacco. J. Gen. Virol., 75: 3185-3191 